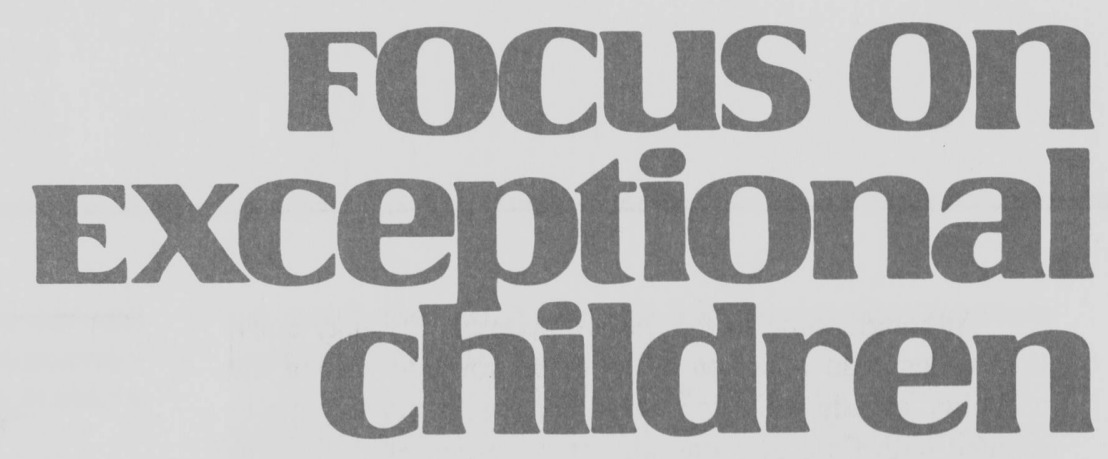

\title{
Practical Questions About Collaboration Between General and Special Educators
}

\author{
Peggy T. Reeve and Daniel P. Hallahan
}

Collaboration between general and special educators has become one of the most popular topics in the special education field. What are the reasons for this emphasis on collaboration and a number of closely related areas-e.g., consultation, inclusion, and the merging of general and special education? Historically speaking, implementation of the Education for All Handicapped Children Act (PL 94-142) in 1975 has been influential. During initial implementation of the act (now known as the Individuals with Disabilities Education Act, IDEA), school systems focused on establishing self-contained programs for students with disabilities, a service delivery model popular in the 1960s. During the 1970s and early 1980s, this emphasis changed when professionals thought the principles of normalization emphasized in IDEA were better served by the resource model of service delivery (Deno, 1970). Most recently, the calls for educational reform, special education restructuring, and full inclusion have provided further impetus for advocates of collaboration between general and special educators.

Given that collaboration has been a popular subject of workshops and of many articles, even entire issues of journals, one would think that we now have a rich research base upon which to draw for recommendations concerning best practices. Unfortunately, this is not the case. Too few researchers have addressed even the most fundamental questions pertaining to the effectiveness of collaboration.

Interestingly, we tend to know more about the process of collaboration than its outcomes. This focus on the interactions between collaborators rather than outcomes for students has been branded as a "feel-good approach" to collaboration (Fuchs \& Fuchs, 1992). We agree wholeheartedly with the Fuchs's call for more research directed toward the efficacy of collaboration. Unfortunately, as with so many current educational initiatives for students with disabilities (e.g., full inclusion, facilitated communication), the proverbial cart (containing prescriptions for practice) is considerably ahead of the horse (forged from research).

Peggy Reeve and Daniel Hallahan are affiliated with the Curry School of Education, Department of Curriculum, Instruction, and Special Education, at the University of Virginia.

C Love Publishing Company, 1994. The copyright for the case portion of this article remains with Daniel P. Hallahan and J.M. Kauffman. 
Although some in the research community may question widespread adoption of collaboration and lament the credulity of administrators who believe it can be implemented with little planning and extra resources, collaboration is fast becoming one of the most popular service delivery models. We have written this article in the interests of helping teachers cope with the myriad questions they will face in working collaboratively. We attempt to answer some practical questions about collaboration, using a teaching case based on an actual experience of a first-year teacher. (The names of all parties have been changed.) By means of this case, we explore several oft-asked questions related to the effective and efficient implementation of collaborative models or programs, referring whenever possible to the research base for these practices.

\section{FOCus on Exceptional children}

ISSN $0015-511 \mathrm{X}$ FOCUS ON EXCEPTIONAL CHILDREN (USPS 203-360) is published monthly except June, July, and August as a service to teachers, special educators, curriculum specialists, administrators, and those concerned with the special education of exceptional children. This publication is annotated and indexed by the ERIC Clearinghouse on Handicapped and Gifted Children for publication in the monthly Current Index to Journals in Education (CIJE) and the quarterly index, Exceptional Children Education Resources (ECER). It is also available in microfilm from Xerox University Microfilms, Ann Arbor, MI. Subscription rates: Individual, $\$ 30$ per year; institutions, $\$ 40$ per year. Copyright (C) 1994, Love Publishing Company. All rights reserved. Reproduction in whole or part without written permission is prohibited. Printed in the United States of America. Second class postage is 'paid at Denver, Colorado. POSTMASTER: Send address changes to:

Love Publishing Company

Executive and Editorial Office

1777 South Bellaire Street

Denver, Colorado 80222

Telephone (303) 757-2579

Edward L. Meyen

University of Kansas

University of Kansas Medical Center

Stanley F. Love

Publisher

\section{Holly T. Rumpler Senior Editor}

\section{Case}

\section{"Yours, Mine, or Ours?": Steve Franklin}

As a resource teacher for eighth-grade students with learning disabilities or behavior disorders, Steve believed his first priority was to ensure his students' success in their mainstream classes. Thus, when he heard about the inclusion model-in the form of the resource teacher working in the regular education class with his students and others, actual team-teaching potential-Steve was excited. He was only a first-year teacher at Wilson Junior High, however, and he did not want to "step on any toes."

$\mathrm{He}$ had heard that the English teacher with whom his students would be placed was excellent with special needs students-demanding, expecting the best, but not unrealistic in her expectations. These qualities, Steve thought, would help ease him, as well as his students, into this new inclusion model. Here, perhaps, would be a place where not only the children would feel part of the mainstream, but Steve as well could feel the satisfaction of working with students on a huge continuum of strengths, abilities, and weaknesses in the general classroom.

Two weeks remained in the summer before the start of the school year, and Steve wasted no time in starting to build rapport with this teacher. He called her one evening to set up a meeting.

"Hello, Pam, this is Steve Franklin. I've just been hired as the resource teacher next year, and I understand you'll be teaching most of my students English. Would it be possible for us to get together sometime soon to discuss possibilities for how we envision our working roles and get to know each other's styles?"

"Sure. Let's meet at my house next Tuesday. Right after noon is good for me. My kids are napping!"

"Great. I'll see you then. I'm really looking forward to this. l've heard great things about your work with special needs students in your classroom."

On the appointed day, Steve and Pam had a productive discussion about the inclusion model. Pam was highly receptive to the proposal, saying that in her 20 years of teaching, several special educators had worked with her in this capacity and that most often it was successful. She stressed that personal styles and philosophies played a key role in these interactions. If the teachers kept open communication, she found, the students invariably benefited from this combination of professionals working toward similar goals for them.

That first day of school, in seventh-period English in Room 317 , two teachers stood in front of the room. They introduced 
themselves to the students as Mr. Franklin and Ms. Jarinski, not differentiating their respective roles as special educator and general educator. For some of the resource students, even, this was their first contact with Mr. Franklin.

Steve and Pam stayed after school late that day to plan the first semester's goals and assignments further, after having the advantage of meeting the students with whom they'd be dealing. Steve was fascinated by Pam's creativity. He also was pleased to hear that Pam's expectations were no lower for his students than for the others, although she was amenable to his suggestions for certain accommodations. For example, Pam wanted students to read The Outsiders and write a summary and reactions to each chapter. Knowing that reading this book, let alone writing detailed analyses, would be difficult for some of his students, Steve created audiotapes for each chapter for the students with particularly low reading ability. Also, for those who could read fairly well (i.e., at grade level) but who shied away from written language assignments, he thought that taking dictation of their summaries and reactions would be a more effective first-novel-of-the-year measure of their comprehension. Pam seemed to be pleased with these accommodations, so Steve felt reassured that she would be open to others he might make in the upcoming year.

Each day Steve looked forward to seventh period. This was a time when he could work with a range of students' ability levels that he hoped would afford a "reality check," a measure against which he could gauge the performance of the students in his caseload. Also, he could see in the regular classroom what behavior and learning differences differentiated his students from the others. For example, Chris took an extra 3-5 minutes to get his materials out; Sherika talked constantly, it seemed, to her neighbor (whomever it may be that day); Shawn and Joe couldn't keep their hands to themselves; April gazed out of the window when directions were given; and Charles, being teased a lot for his weight and "strange" behaviors (picking his nose, talking to himself), always seemed dejected.

Because of all of these individual differences and occasional need for crisis intervention, Steve's role in the classroom began to evolve from what he had originally planned. Suddenly, it seemed, Pam was the teacher in the front of the blackboard while Steve "floated" through the classroom arena, helping to clarify directions, organizing students, editing students' writing, administering positive reinforcement to students who were behaving appropriately and on task, and defusing fights before they could erupt (or dealing with the post-altercation discipline).

Frustrated and unsure of the situation, he asked Pam, "Am I doing a good job? I don't intend to sound unrealistic, but is this the way it's worked with the resource teachers involved in inclusion in the past?"

"Steve, you're doing a fabulous job. I don't think I could reach this group if I didn't have your help. The things you do in class are so valuable for all of the kids, not just the identified students."

"Yeah, but I often think that if you didn't have to deal with the tough emotional and learning needs of my kids, your day would go much smoother. I wish I could do more for you than I do."

"Hey, Steve, they're not just your kids-they're ours."

This woman was like a special educator's dream: Her concepts of inclusion and her philosophy about the special needs children were so great they were almost a cliché! Always in the back of Steve's mind, however, was the knowledge that this team of teachers, led by Pam Jarinski, did not have to take Steve's caseload every year. Pam and Steve did not make any more money than the rest of the teachers in the school, yet they dealt with some tough issues with the students with specific disabilities. Steve wanted to know that he and his students would be invited back to this classroom next year and for years to come.

Difficulties in the seventh-period class continued. Steve and Pam anticipated this class less and less as the year went on. By the second 9-week grading period, Steve noticed that not just "his students" were difficult to instruct in this setting. Of course, part of the problem was that this was the last period of the day, and interactions had built to the boiling point with some of the eighth graders by the time they got to the Franklin/Jarinski connection. Also, energy levels were low for students who weren't out of their seat or talking with others. Some seemed as if they could use that afternoon nap afforded to the lucky kindergartners! Looking at the "tired" ones made Pam and Steve feel even less successful. The ultimate frustration for them, however, was the disappointed, rolling-of-eyes look on the faces of the students who were there each day ready to learn but who had to wait out the disruptions of the students around them.

Steve continued to do much of the "behind the scenes" work, planning and organizing differentiated activities for the class, but he worked less and less in front of the class. Although Pam and Steve never spoke of it, it became evident that this was the way they would work the class: Pam in front, giving instruction, and Steve still "floating." He thought back to their original meeting and the emphasis Pam had put on communication. They both were so busy keeping up with the kids, however, that they barely had time to talk except when they saw each other in seventh period. Once there, they were two people in the same room doing entirely differ- 
ent jobs! While Pam had her planning period, Steve was pulling kids from their Enriching Arts classes, so he had a full resource class of six students. Occasionally he could scoot next door to set plans for the day, but the two teachers rarely had the opportunity to sit down and discuss the many and varied interactions, responses, and difficulties that transpired each day during seventh period.

Steve was beginning to have serious difficulties with the concept of teacher collaboration as it was manifesting itself in Room 317. Although he maintained the utmost professional and personal respect for Pam, he could not help believing that this situation was not best serving his students or feeling dissatisfied with the team-teaching responsibilities he had hoped for.

Steve's internal pressure to do better got worse one day when a critique came from a new, unexpected source: a student. Shawn, one of the students with behavior disorders, had continued to have trouble keeping his hands to himself, despite the contracts and self-monitoring strategies Steve had worked on with him. One day Steve had approached Shawn's desk, knelt down, and whispered to him to give Lucy's pencil back to her. Shawn turned away from him, saying, "You're not the teacher here anyway. You're the resource teacher. You should be in your room helping kids and stuff."

Steve's first thought was, "Who is this little guy to tell me how I should do my job?" His second thought was to realize that not only he, but other kids as well, were confused about Steve's role. Their experiences with their resource teachers most likely would have been with the pull-out model. Also, they did not know all of the behind-the-scenes planning Steve did with Pam. What they saw each day in the class did not look much like a teacher partnership.

One day the behavior of the class was particularly horrendous, bad enough that both Pam and Steve decided to spend some heartfelt, dedicated time after the long day to discuss their next move. The idea they came up with for behavior management was to group the students into teams and give each team token reinforcement for appropriate behaviors (e.g., attention-to-task, helping teammates, having materials out) and removing it for inappropriate behaviors (e.g., talking out, not having materials, not attending to task). The teachers were clear about the parameters for this system when they presented it to the students, and they believed it was not too complicated to work.

The physical change within the classroom was fairly radical: Steve and Pam moved all of the desks to an empty room at the end of the hall and exchanged them for tables. They arranged the students into groups of four, mixing ability lev- els but minimizing interaction and behavior difficulties. The tokens they gave were "fake" money bills that each group could amass and cash in at the end of the grading period. Each group's name was on the board, and money was taken away or given as deserved in the appropriate column so the students would see their accumulation and loss of rewards immediately.

This plan was fairly successful for a few weeks. The students motivated the others in their group to work hard, stay on task, and behave appropriately. When students "messed up," Pam or Steve was not always the person calling them on it. Now the students had a major role in behavior management.

Steve, however, still had a minimal part in the plan, as far as classroom time was concerned. Pam was the one in front of the room with the chalk, so by mere fact of physical proximity to the "rewards" board, she was the one to award and withdraw the tokens. Steve had hoped this system would have afforded him a higher profile in the class.

After the novelty had worn off the token system, problems continued in the classroom. Pam and Steve realized that keeping up with the system demanded more of their time and patience than they had hoped. Steve was disappointed that this was not working, but it was helpful for him to see that strategies that might work in a smaller group or self-contained special education setting were far more difficult to implement with the large group. As always, his admiration for what Pam's job was like did not change.

Steve was late to seventh period the next Monday, as he'd gotten his finger caught in his file cabinet rushing to tie up loose ends from sixth period, and he went to the clinic to put ice on it. It's amazing what can happen when you're gone for 10 minutes.

He came to Room 317, opened the door, and saw many somber faces in front of him. They all looked at him and then at Ms. Jarinski. Steve sat down next to her at the table and furrowed his brow for some explanation about what was going on. Pam handed him a list of four names, all resource students, and said, loud enough for all the students to hear, "I think we have to self-contain these kids for the rest of the year. It goes against my philosophy, but they just can't seem to control themselves."

Yes, only 3 weeks remained in school, but Steve was shocked. Without changing their IEPS, this would not be legal, and he believed this should not be the final solution, nor was it the message he wanted to send these kids: that they are incapable of controlling their behavior and, thus, cannot be accepted in the mainstream English class. What could he do without damaging his relationship with Pam? 
Although this is an actual case, we are not informed of all the interventions the teachers may have tried or of what happened to collaboration between Pam and Steve after the final incident in this case. Any teaching case lacks some information of value to readers as they try to analyze the strengths and weaknesses of the case. Given some gaps in information, we have chosen to address four questions central to implementation of a collaborative program in general education classrooms, questions we believe elucidate what might have gone wrong with this collaboration.

\section{QUESTIONS}

\section{What forms can collaboration take in the classroom?}

How one defines collaboration or what forms this collaboration takes in actual practice are as unique as students' needs and philosophies of the teachers and administrators involved. In the case of Steve and Pam the expected roles for each teacher were not defined clearly. Clearly, however, Steve had expected that he would have a greater role in instruction in the classroom.

\begin{abstract}
Steve's role in the classroom began to evolve from what he had originally planned. Suddenly, it seemed, Pam was the teacher in the front of the blackboard while Steve "floated" through the classroom arena, helping to clarify directions, organizing students, editing students' writing, administering positive reinforcement to students who were behaving appropriately and on task, and defusing fights before they could erupt (or dealing with the post-altercation discipline).
\end{abstract}

\section{Consultation/Collaborative Consultation}

One service delivery option that has received much attention is consultation and a more recent variation known as collaborative consultation. Consultation has been used as a prereferral intervention as well as a component in the individualized education program (IEP) of identified students. Although the roots of consultation can be traced back hundreds of years, its use as a form of service delivery in the schools dates back to the late 1960s and early 1970s (Friend, 1988; Schulte \& Osborne, 1993). During this time professionals employed some form of the expert model of consultation, wherein a school support personnel member (most often the school psychologist) analyzed the problem, evaluated the options, and prescribed a treatment or intervention for the teacher to carry out. Some have criticized the expert model for its hierarchical orientation, which often characterizes general educators as needing assistance and specialists as being sources of assistance (Pugach \& Johnson, 1988).

In contrast to the expert model of consultation, West and Idol (1990) have called for a collaborative consultation model, both as a problem-solving process and as a service delivery mechanism. Unlike the consultant and consultee relationship in the expert model of consultation, both the consultant and the consultee are active at all stages of consultation (problem identification, assessment, strategy selection, strategy implementation, and evaluation) and share responsibility for all stages. In this model, as in the expert model, the consultee retains the primary responsibility for direct service to the student(s). West and Idol suggested that several vehicles exist for collaborative consultation. Some examples are teacher assistance teams, intervention assistance teams, school-based resource teams, student support teams, and child study teams. The basic ingredients that differentiate collaborative consultation and other consultation approaches are parity in the generation of solutions and shared responsibility for outcomes.

Some have questioned whether effective collaborative consultation is actually nondirective (Erchul, 1993; Schulte, Osborne, \& Kauffman, 1993; Witt, 1990). In studies employing several different coding systems, Erchul (1993) analyzed, on the basis of social power, the conversation in school-based consultation interviews and found that the effective consultant (evaluated by the consultees) typically controls the interview direction. Moreover, he found that consultees who attempted to control the direction of the interview were less likely to participate in data collection.

Similarly, Schulte et al. (1993) investigated elementary general education teachers' responses to two types of consultative special education services. One model combined teacher consultation and direct instruction. The other model used only consultation. Teachers expressed their views through pre/post questionnaires and an interview. The results demonstrated that teachers:

- preferred a model that involved collaboration between general and special educators across all stages of problem solving.

- preferred consultation over referral, although those receiving only consultation lost this preference over time. 
- saw problems as more severe after consultation/direct instruction but considered themselves more capable of dealing with the problems than teachers in the consultation-only model.

The research on consultation and collaborative consultation and their relationship to special education is limited and subject to much criticism. Fuchs, Fuchs, Dulan, Roberts, and Fernstrom (1992) conducted a review of the empirical literature on consultation effectiveness from 1961 to 1989 and found that the median number of databased publications on this topic was fewer than five per year. Four outcome measures (systematic observation of teachers or students, questionnaire or interview responses, teacher ratings of students, and student achievement) were used alone or in combination to judge the success of consultation. Whereas investigators used student or teacher behavior in nearly two thirds of the studies to measure success of consultation, they used student achievement in only one quarter of the studies. Several authors (Fuchs \& Fuchs, 1992; Gresham \& Kendell, 1987; West \& Idol, 1987) agree that definitional confusion, methodological flaws, and lack of assessment of treatment integrity (implementation of treatment or intervention as planned) have left the field of consultation research open to criticism.

\section{Cooperative Teaching}

Another form of collaboration between general and special educators is found in the cooperative teaching or coteaching model. Bauwens, Hourcade, and Friend (1989) suggested that cooperative teaching "represents the multidisciplinary implementation phase of the program planning that evolves out of collaborative consultation" (p. 18). In cooperative teaching both general and special education teachers are present simultaneously in the general classroom with joint responsibility for instruction. Bauwens et al. posited that the cooperative teaching model brings together and uses effectively the unique and specific skills of each professional. The general educator is particularly knowledgeable about curriculum and curricular sequencing and is skilled and experienced in large-group management, whereas the special educator is an expert in task analysis, curriculum modification, and behavior management.

In the case, Steve was impressed with Pam's expertise and creativity with the curriculum. Likewise, Pam appreciated Steve's skills in the area of modification of curriculum and adaptation of instructional materials and strategies, as well as his expertise in applied behavior analysis.

One can implement cooperative teaching via several classroom arrangements (complementary instruction, team teaching, and supportive learning activities) that should not be viewed as mutually exclusive (Bauwens et al., 1989). The teaching arrangement best suited to the participating teachers, students, and classroom evolves out of close planning and evaluating by the general and special educators.

In a complementary instruction approach the general educator maintains the primary responsibility for subject matter instruction, and the special educator is responsible for the students' mastery of academic skills necessary to acquire the subject matter content. The special educator might prepare units of instruction on note taking, attending, or specific prerequisite skills integral to the lesson and instruct any students who need to develop these skills. The complementary instruction approach might be especially appropriate at the secondary level.

In a team teaching approach, the special educator and the general educator jointly plan and teach academic subject content to all students. Given the emphasis on acquisition of basic facts at the elementary level, the team teaching approach might be particularly appropriate here. On occasion one teacher may assume primary responsibility for a type of instruction or a portion of the curriculum. For example, the special educator may introduce a lesson by using direct instruction to introduce new vocabulary, and the general educator may present the rest of the lesson. The teachers also share the monitoring of student attention to, and acquisition of, the content.

In the supportive learning activities approach to cooperative teaching, the general educator maintains responsibility for presenting the content of the instruction and the special educator implements supplementary activities. These activities have been created cooperatively by the general educator and special educator. Both teachers are present in the classroom and responsible for monitoring the learning activities of all students.

What collaborative model might be applied to the arrangement between Pam and Steve in this case? Certainly it did not look like the traditional expert model of consultation. Steve, the special educator, did not see himself, nor was he seen, as the expert in the dyad. Pam maintained the primary responsibility for instruction. The case suggested that Steve's role in the classroom evolved from what he 
expected and that he worked less and less in front of the class, indicating that at one time he may have had some instructional responsibility. Steve perceived his work as consisting of behavior management and "behind the scenes" planning and organizing of differentiated activities, which might be a combination of the complementary approach and the supportive learning activities approach. The problems with Steve's and Pam's arrangement might have had less to do with what they did in the classroom (the approach or model) and more to do with how they and the students perceived the situation, how the teachers communicated their roles to each other and the students, and the actual outcomes (social, behavioral, and academic) for the students.

\section{What essential skills, qualities, and competencies do general and special educators need for effective collaboration?}

Steve and Pam both expressed their views on what makes collaboration successful. Although Steve's experience with collaboration was limited, given that he was a first-year teacher, he was pleased with many of Pam's qualities because he thought Pam would be able to "help ease him, as well as his students, into this new inclusion model." Among Pam's qualities with which Steve was impressed was her reputation with special needs students-“demanding, expecting the best, but not unrealistic in her expectations." Further, he found that "Pam's expectations were no lower for his students than for the others, although she was amenable to his suggestions for certain accommodations."

Pam, being the veteran teacher, suggested that in her 20 years of teaching, she had participated in several collaborative situations with special educators. She stressed that "personal styles and philosophies played a key role in these interactions." Another important factor in the success of collaboration, as seen by Pam, was "open communication." She had found that, with good communication, "the students invariably benefited from this combination of professionals working toward similar goals for them."

The literature supports Steve's and Pam's thoughts about qualities and values associáted with effective collaboration (Nowacek, 1992; Trent, 1992). In interviewing five collaborating teachers Nowacek (1992) found that three of the five placed great importance on having the "right person" with whom to collaborate. One teacher's comments summarized this importance. She opined that school systems would be making a mistake to train teachers and designate which two teachers are to work together. She stated, "That would not work at all. Carol and I have a relationship where it works. I'm sure there are other teachers I couldn't work with. I think it's very person-specific" (p. 274). Another teacher described how she and two other special educators selected general educators to approach about collaborating. Their two considerations were someone who might be willing to collaborate and someone who was considered a strong teacher.

Nowacek's (1992) teachers also expressed the importance of communication: "We really had close communication. We didn't share a common planning period, so we communicated . . . before school, over lunch, after school. At these times we'd talk about how the lesson went, how we could make it better" (pp. 266-267).

West and Cannon (1988) surveyed a 100-member interdisciplinary, expert panel from 47 states on the knowledge, skills, attitudes, and characteristics needed for engaging in the consultation process. These experts identified $47 \mathrm{com}$ petencies in eight categories as essential to the consultation process. The five categories receiving the highest mean ratings centered on interpersonal skills, personal and professional attitudes and beliefs, and personal attributes necessary for collaborative communication.

Although West and Cannon offered these competencies as they pertain to the collaborative consultation process, the 10 individual competency statements (from three of the five categories mentioned above) receiving the highest mean ratings (3.9 to 4.0 on a 4.0 Likert-type scale) with little modification could apply to other collaborative situations. Specifically, seven statements from the Interactive Communication category are worth mentioning:

1. Communicate clearly and effectively in oral and written form.

2. Utilize active ongoing listening and responding skills to facilitate the consultation process.

3. Interview effectively to elicit information, share information, explore problems, set goals and objectives.

4. Give and solicit continuous feedback that is specific, immediate, and objective.

5. Give credit to others for their ideas and accomplishments.

6. Manage conflict and confrontation skillfully throughout the consultation process to maintain collaborative relationships. 
7. Be willing and safe enough to say, "I don't know. Let's find out."

Steve continued to maintain his professional and personal respect for Pam, even though he thought the situation was not best serving the identified students and he was disappointed with the division of responsibilities in the partnership. Perhaps at issue in the case was the discrepancy between Pam's and Steve's experience (Pam with 20 years' experience and Steve in his first year). Possibly, Steve felt, as a novice he could not voice his frustration with the situation to this veteran teacher. Perhaps Pam implemented her usual style and format of teaching, comfortable with her successes of the past and unwilling to restructure her class for this collaboration.

Both the research literature and the case of Pam and Steve suggest that compatibility of beliefs and attitudes and the ability to work together lead special and general educators to perceive collaboration positively. Neither the research nor the case, however, tells us much about teaching skills that special and general educators need in collaborative arrangements. West and Cannon (1988) chose not to include in their survey of experts the technical skills associated with effective teaching of students with disabilities or at-risk students. An interesting question to ponder is whether professionals should rely solely on ability to get along and communicate? Perhaps compatibility is a necessary but not sufficient condition for successful collaboration, especially when student outcomes are the dependent measure.

\section{What are the major barriers/facilitators to effective collaboration?}

The ability to communicate openly has been noted as one of the skills or qualities associated with successful collaboration. Pam and Steve indicated their awareness of the importance of communication but did not communicate their concerns and frustrations to each other. Steve spoke of the lack of time for communication:

Although Pam and Steve never spoke of it, it became evident that this was the way they would work the class: Pam in front, giving instruction, and Steve still "floating." He thought back to their original meeting and the emphasis Pam had put on communication. They both were so busy keeping up with the kids, however, that they barely had time to talk except when they saw each other in seventh period. Once there, they were two people in the same room doing entirely different jobs! While Pam had her planning period, Steve was pulling kids from their Enriching Arts classes, so he had a full resource class of six students. Occasionally he could scoot next door to set plans for the day, but the two teachers rarely had the opportunity to sit down and discuss the many and varied interactions, responses, and difficulties that transpired each day during seventh period.

The lack of planning and evaluation time is well documented in the literature as a barrier to successful collaboration (Bauwens et al., 1989; Idol \& West, 1987; Nowacek, 1992; Reisberg \& Wolf, 1986; Trent, 1992). For example, in a follow-up study of master's level resource/consulting teacher program graduates, Idol-Maestas and Ritter (1985, as cited in Idol \& West, 1987) reported that time to consult was the single most important factor in initiating and continuing the consultation role.

As a potential solution to the time crunch, the need for administrative support for collaborative arrangements between general and special educators is proclaimed repeatedly in the literature (Idol \& West, 1987; Nowacek, 1992; Reisberg \& Wolf, 1986). Administrative leadership sets the tone for innovative practices and their acceptance by teachers who follow the administrative lead.

If Steve and Pam had had the support of the administration, they might have approached administrators with a request for a common planning time or, if that were not possible, release time for some portion of the hours necessary to plan effectively. Planning time for teachers to interact professionally has been postulated as one of the hallmarks of school reform proposals (Carnegie Forum, 1986; Holmes Group, 1986). Pugach and Johnson (1988) suggested that, while waiting for sweeping time reform in schooling, schoolwide schedules could be reorganized so the time of various content-area specialists (e.g., music, art, physical education) would allow a subgroup of teachers (possibly grade-level teachers) to meet regularly for the purpose of problem-solving. Another creative suggestion from Pugach and Johnson (1988) involves principals reserving faculty meetings regularly (for example, every third meeting) for consultation purposes.

Additional barriers to collaboration have been pointed out. Teachers have expressed concerns about the possible difficulties professionals may have in developing cooperative working relationships, the resistance by colleagues to a 
radical shift in the service delivery model, and increased workloads for general and special educators alike (Bauwens et al., 1989). In Nowacek's (1992) interviews with collaborating teachers, all five teachers feared that collaboration might become the only service delivery model considered, replacing other special education services they believe are appropriate for some students. One teacher advised, "We [special educators] still have legal requirements to identify children with special needs. I have some students that I need to pull out for therapy, especially children who have articulation, fluency, and voice problems" (p. 274).

\section{What are the potential benefits or outcomes of collaboration between general and special educators?}

From the case, Steve and Pam clearly expected their collaboration in the classroom to benefit not only themselves but also their students. At the beginning, Pam stated that her experience has been that students benefited from "this combination of professionals working toward similar goals for them." She further commented to Steve, "I don't think I could reach this group if I didn't have your help. The things you do in class are so valuable for all of the kids, not just the identified students."

These sentiments have been expressed by collaborating teachers in practice. Nowacek's (1992) sample of teachers identified instructional benefits, affective benefits, and professional benefits. One teacher stated five advantages she observed from an instructional viewpoint:

1. Collaboration provides an additional level of service between resource services and monitor status in which the resource teacher consults with the general educator but does not provide direct services to students.

2. It provides more services to students who need it. Students may be in one or more collaborative classes and receive a pull-out resource class as well.

3. It allows some students to be mainstreamed who would not be able to be successful in the general classroom unless a special educator were also present.

4. It provides services to students who have not been found eligible for special education but who need additional help.

5. Most of the special education students and many of the general education students think this arrangement is helpful to them.
Two teachers described affective outcomes for students and teachers alike. One teacher perceived that students feel less stigmatized or singled out by participating in collaborative classes. She mused that students feel more normal by carrying the "regular" book and doing what the other students are doing. Another teacher expressed her greater respect for students with disabilities as a result of collaborating with a special educator. She considered herself better able to see their disability as an identifiable condition instead of looking at them as lazy students. She also learned that she as a teacher can help with these problems or can compound them.

Professional benefits of collaboration included the opportunity to work with more students and students from a wider spectrum of abilities. Teachers enjoyed sharing knowledge and instructional techniques that helped to break the isolating nature of teaching. Teachers also saw their students in different situations, which often brought them to appreciate the students' efforts and to be more patient in working with them.

In the case, the outcomes were not as positive, even though Steve and Pam began this collaboration with great expectations. Steve was frustrated with his role in the classroom and with the situation for his students. Steve also noted that his students were not the only ones who were difficult to instruct in this setting. Both Pam and Steve were concerned and discouraged by the "disappointed, rolling-of-eyes look on the faces of the students who were there each day ready to learn but who had to wait out the disruptions of the students around them." The case did not give information on the students' academic achievement, but we might safely assume that many students were not reaching their potential.

The decision to use collaborative methods in the classroom as a means to deliver services to identified and at-risk students must be based on the assurance that this form of service delivery will best serve these students by improving their academic, social, and behavioral standing. These expected and hoped-for outcomes must be planned for and continually monitored and evaluated.

Zigmond and Baker (1990) noted the importance of planning, support, and training in the success of reintegrating students into the general education classroom. During a full year of preparation prior to returning students with learning disabilities to the general education classrooms, general education teachers participated in inservice training in alternative strategies for teaching reading and in curriculum based assessment (CBA) techniques. Once the students 
were integrated fully into the mainstream classrooms, CBA was implemented with a microcomputer information system and weekly problem-solving sessions. In addition, the entire staff participated in ongoing inservice training, which included a workshop on new methods on teaching literacy skills and instruction on behavior management techniques.

Despite the rigorous planning and implementation, the mainstream teachers in Zigmond and Baker's (1990) project did not consistently change grouping patterns for reading or math instruction, did not respond to CBA data by changing instructional programs for individual students, and did not significantly alter the style, pace, or sequence of reading instruction. As a result, students made no significant progress in reading and math. Zigmond and Baker (1990) and Fuchs, Fuchs, and Fernstrom (1993) asserted that "business as usual," whether it be in special or general education classrooms, often fails students with disabilities.

\section{CONCLUSIONS}

The case presented in this article started out with two enthusiastic, energetic, and cooperative teachers who were interested in meeting the needs of a diverse classroom population. It ended with two frustrated teachers and a classroom of students who did not respond (either academically or behaviorally) to the teachers' efforts in the way they had hoped. A list of the possible reasons for the failure of this collaborative venture might include: lack of definitive teacher roles from the beginning, lack of administrative support, lack of time for joint planning and evaluation, lack of assertiveness on the part of a novice special educator, resistance to change on the part of a veteran general educator, lack of experience on the part of the special educator, and lack of technical skills on the part of both educators.

Delineating the possible obstacles to successful collaboration in the case illuminates how complicated the process can be. After reading the case, one is keenly aware that effective collaboration requires more than two educators with good intentions. Participants in collaboration must plan for careful implementation and continual monitoring and evaluation. Several authors (e.g., Fuchs \& Fuchs, 1992; Kauffman \& Trent, 1991) have asserted that what happens between student and teacher in the classroom is of utmost importance and cannot be sacrificed or take a back seat to the collegiality between general and special educators. Pro- fessionals must judge models of collaboration by their effect in changing what transpires for students during instruction.

In addition to the appeal of having a partner in teaching students with challenging needs, teachers are attracted to collaboration as a service delivery model because of the possibility of more intense services for students. Teachers have indicated that collaboration provides another level of service (between monitor status and resource room) for students and also provides more services to students who may need it by allowing their participation in collaborative classes, as well as a pull-out resource class (Nowacek, 1992). D. Huefner (personal communication, June 8, 1993) agrees with Kauffman and Trent (1991) that "while a need exists to establish and strengthen collaborative programs, they should not be assumed to replace other special education service delivery models" (p. 471).

We have not presented this case and our commentary to suggest that collaboration is not a viable service delivery or that all collaboration is doomed to failure but, instead, with the hope of presenting a realistic picture of the difficulties and pitfalls that may accompany collaborative efforts. Researchers and practitioners have demonstrated the promising qualities of collaboration as a means to serve the special needs of students in a general education classroom. Future researchers, in collaboration with teachers in the field, will clarify the skills and practices that make collaborative efforts successful.

\section{REFERENCES}

Bauwens, J., Hourcade, J., \& Friend, M. (1989). Cooperative teaching: A model for general and special education integration. Remedial \& Special Education, 10, 17-22.

Carnegie Forum on Education and the Economy. (1986, May). A nation prepared: Teachers for the 21st century. New York: Carnegie Corp.

Deno, S. L. (1970). Special education as developmental capital. Exceptional Children, 37, 229-237.

Erchul, W. P. (1993, April). Is collaborative consultation non-directive? In D. Fuchs (Chair), Questioning popular beliefs about collaborative consultation. Symposium conducted at meeting of Council for Exceptional Children, San Antonio, TX.

Friend, M. (1988). Putting consultation into context: Historical and contemporary perspectives. Remedial \& Special Education, 9, 7-13.

Fuchs, D., \& Fuchs, L. S. (1992). Limitations of a feel-good approach to consultation. Journal of Educational and Psychological Consultation, 3, 93-97.

Fuchs, D., Fuchs, L. S., Dulan, J., Roberts, H., \& Fernstrom, P. (1992). Where is the research on consultation effectiveness? Journal of Educational \& Psychological Consultation, 3, 151-174. 


\section{NEW FOR 1994}

\section{The Teddy Bear Express! \\ A PHONOLOGICAL REMEDIATION PROGRAM FOR SPEECH \\ CLINICIANS, TEACHERS, AND PARENTS}

NANCY J. BONSANGUE SUSANNE G. FLATLEY

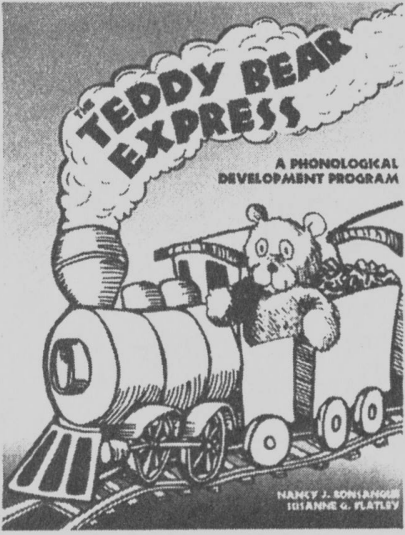

The Teddy Bear Express! addresses the phonological development of young children. All the materials were developed with parental involvement in mind. Although parental involvement in weekly sessions with the speech/language pathologist is strongly encouraged, it is not essential, providing parents are given guidance and are committed to completing the home activities.

Each lesson focuses on a particular phonological process. Lessons are written for a small group of children (approximately five or six) but can be adapted for use in a classroom setting. Lessons can also be adapted for sessions with individual children. All lessons have been developed with regard to a young child's interest and natural environment.

Sharing, music, and literature are activities that help reinforce the targeted concept. Sharing is encouraged to foster speech production practice and interaction. Songs and stories are chosen based on familiarity and appeal to young children, as well as how effectively they rein- force a particular concept. Included in each lesson are suggestions for songs and stories. A word list is also included in each lesson for auditory stimulation. It is read and then sent home to be read by the parent daily. All the words on the word list contain the phoneme that was used to present the phonological process during that session.

The program is particularly suited for young children in Head Start, regular education preschool, kindergarten, and firstgrade classrooms to reinforce their communication skills.

9308/paperback/ISBN $\quad 0-89108-232-8$

$\$ 24.95$

\section{ORDER FORM..... Yes!' want to order The Teddy Bear Eipresst}

Mail to:

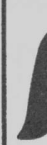

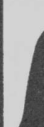

LOVE

PUBLISHING

COMPANY

1777 South Bellaire Street Denver, Colorado 80222

Check enclosed

Purchase order

Charge: $\square$ Visa

Mastercard
Please send copies TODAY.

List Price:

$\$ 24.95$

Shipping and Handling: $\quad 2.00$

TOTAL

Name

Address

City State Zip

Telephone

Name on Card

Account \# Expires 
Fuchs, D., Fuchs, L. S., \& Fernstrom, P. (1993). A conservative approach to special education reform: Mainstreaming through transenvironmental programming and curriculum-based measurement. American Educational Research Journal, 30, 149-177.

Gresham, F. M., \& Kendell, G. K. (1987). School consultation research: Methodological critique and future research directions. School Psychology Review, 16, 306-316.

Holmes Group. (1986). Tomorrow's teachers: A report of the Holmes Group. East Lansing, MI: Author.

Idol, L., \& West, J. W. (1987). Consultation in special education: Part 2. Training and practice. Journal of Learning Disabilities, 20, 474-494.

Kauffman, J. M., \& Trent, S. C. (1991). Issues in service delivery for students with learning disabilities. In B. Y. L. Wong (Ed.), Learning about learning disabilities (pp. 465-481). San Diego: Academic Press.

Nowacek, J. E. (1992). Professionals talk about teaching together: Interviews with five collaborating teachers. Intervention in School \& Clinic, 27, 262-276.

Pugach, M. C., \& Johnson, L. J. (1988). Rethinking the relationship between consultation and collaborative problem-solving. Focus on Exceptional Children, 21, 1-8.

Reisberg, L., \& Wolf, R. (1986). Developing a consulting program in special education: Implementation and intervention. Focus on Exceptional Children, 19, 1-14.
Schulte, A. C., \& Osborne, S. S. (1993, April). In the eye of the beholder: Collaborative consultation definitions and research. Paper presented at meeting of Council for Exceptional Children, San Antonio, TX.

Schulte, A. C., Osborne, S. S., \& Kauffman, J. M. (1993). Teacher responses to two types of consultative special education services. Journal of Educational \& Psychological Consultation, 4, 1-27.

Trent, S. C. (1992). Collaboration between special education and regular education teachers: A cross-case analysis. Unpublished doctoral dissertation, University of Virginia, Charlottesville.

West, J. F., \& Cannon, G. S. (1988). Essential collaborative consultation competencies for regular and special educators. Journal of Learning Disabilities, 21, 56-63.

West, J. F., \& Idol, L. (1987). School consultation (Part I): An interdisciplinary perspective on theory, models, and research. Journal of Learning Disabilities, 20, 388-408.

West, J. F., \& Idol, L. (1990). Collaborative consultation in the education of mildly handicapped and at-risk students. Remedial \& Special Education, 11, 22-31.

Witt, J. C. (1990). Collaboration in school-based consultation: Myth in need of data. Journal of Educational \& Psychological Consultation, 1, 367-370.

Zigmond, N., \& Baker, J. (1990). Mainstream experiences for learning disabled students (Project MELD): Preliminary report. Exceptional Children, 57(2), 176-185.

\section{PERMISSIONS AND COPYRIGHT}

All rights are reserved. No part of this publication may be reproduced, photocopied, faxed, stored in a retrieval system, or transmitted, in any form or by any means, electronic, mechanical, recording or otherwise, without the prior written permission of the publisher.
Back issues are available for sale. Reproduction requires permission and payment of fees. It is illegal and a violation of federal copyright law to reproduce this publication without permission. Direct all inquiries to the permissions editor. 